\title{
SOCIAL SUPPORT PERCEIVED BY CANCER PATIENTS AND ITS RELATION WITH SOCIAL AND DEMOGRAPHIC CHARACTERISTICS ${ }^{a}$
}

Adriane Cristina Bernat KOLANKIEWICZ ${ }^{\text {b }}$ Marina Mazzuco de SOUZAc, Tânia Solange Bosi de Souza MAGNAGO ${ }^{d}$, Edvane Birelo Lopes DE DOMENICO

\section{ABSTRACT}

To analyze the relation between social support and socio-demographic characteristics of oncology patients. Transversal study, developed with oncology patients living in the Ijuí city, Rio Grande do Sul state, Brazil between July and December 2012, the population was selected through convenience. For data collection we used the Brazilian version of the Social Support Scale and the Medical Outcomes Study data were analyzed with descriptive statistics

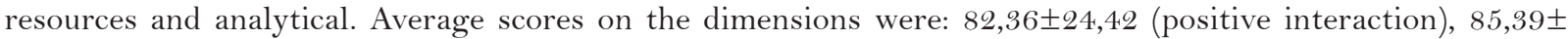
19,81(information), 87,98 $\pm 18,68$ (emotional support), 88,52 $\pm 18,56$ (material support) and 93,50 $\pm 14,44$ (affective support). Evidences showed higher averages in male mulattos patients $(p<0,05)$. There was a direct and growing relationship between per capita income, social support and affective positive interaction. It was proven that patients receive social support in all dimensions, with high scores, but with variations, considering the characteristics of gender, civil status, educational level, per capita income and race.

Descriptors: Social support. Neoplasms. Therapeutics.

\section{RESUMO}

Analisar a relação entre o apoio social e características sociodemográficas de pacientes oncológicos. Estudo transversal, realizado com 268 pacientes oncológicos, residentes no Município de Ijuí, Rio Grande do Sul, Brasil, no período entre julho e dezembro de 2012. Para a coleta de dados, utilizou-se a versão brasileira da Escala de Apoio Social do Medical Outcomes Study e os dados foram analisados

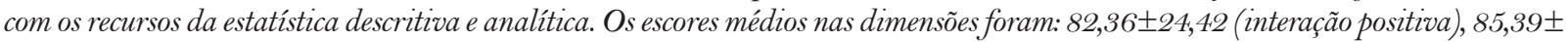

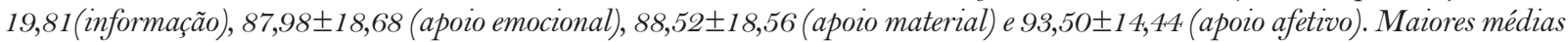
foram obtidas entre os pacientes do sexo masculino e etnia parda $(p<0,05)$. Houve relação direta e crescente, entre renda per capita, apoio social afetivo e interação positiva. Evidenciou-se que os pacientes recebem apoio social em todas as dimensões, com elevados escores, porém com variações, considerando as características sexo, estado civil, escolaridade, renda per capita e etnia.

Descritores: Apoio social. Neoplasias. Terapêutica.

Título: Apoio social percebido por pacientes oncológicos e sua relação com as características sociodemográficas.

\section{RESUMEN}

Analizar la relación entre el apoyo social y las características sociodemográficas de los pacientes oncológicos. Estudio transversal, cuantitativo realizado con 268 enfermos de cáncer que residen en la ciudad de Ijuí / Rio Grande do Sul, Brasil, entre julio y diciembre de 2012. Para la recolección de datos se utilizó la versión brasileña de la Escala de Apoyo Social y los datos del estudio los resultados médicos se analizaron con los recursos estadísticos descriptivos y analíticos. Las puntuaciones medias en las dimensiones fueron 82,36 \pm 24,42 (interacción positiva), 85,39 $\pm 19,81$ (información), 87,98 $\pm 18,68$ (apoyo emocional), $88,52 \pm 18,56$ (apoyo material) y 93,50 $\pm 14,44$ (apoyo afectivo). Puntuaciones medias más altas son encontradas entre los pacientes de sexo masculino y mulatos $(p<0,05)$. Se observó relación directa y creciente entre el ingreso per capita, el apoyo social afectivo y la interacción positiva. Se comprobó que los pacientes reciben apoyo social en todas las dimensiones, con altas puntuaciones, pero con variaciones, teniendo en cuenta las características de género, estado civil, educación, ingreso per capita y raza.

Descriptores: Apoyo social. Neoplasias. Terapéutica.

Título: Apoyo social percibido por pacientes de oncología y su relación con características sociodemográficas.

a Article based on the doctorate thesis, Relações entre os sintomas clínicos, o apoio social e a interferência na vida diária de pacientes oncológicos (Relationship between clinical symptoms, social support and interference in the daily lives of cancer patients) presented at the Federal University of São Paulo (UNIFESP).

b Nurse. PhD in Science. Professor at the Department of Life Sciences (DCVida) of the Universidade do Noroeste do Estado do Rio Grande do Sul (UNIJUí). Ijuí. Rio Grande do Sul. Brazil

c Nursing Scholar. Scholarship student of the Institutional Scientific Initiation Scholarship Programme. UNIJUÍ.

d Nurse. PhD in Nursing. Adjunct Professor, Department of Nursing /CCS, Federal University of Santa Maria. Santa Maria. Rio Grande do Sul. Brazil

e Nurse. PhD in Nursing. Adjunct Professor at the Department of Clinical and Surgical Nursing of the Paulista School of Nursing. UNIFESP. São Paulo, Brazil 


\section{INTRODUCTION}

Non-communicable diseases (NCDs), including cancer, are responsible for $58.5 \%$ deaths and $45.9 \%$ of the global cancer burden, and are consequently configured as a public health problem both in rich and low-income countries (1). In Brazil, they represent $72 \%$ of causes of death and affect the poorer population and more vulnerable groups ${ }^{(1)}$.

Cancer is often interpreted as a disease of stigma and a synonym of suffering and death. It can compromise the lives of patients physically, psychologically or socially, and is considered a disease of progressive and aggressive evolution, with debilitating symptoms and prolonged treatment that is associated to the side effects of radiotherapy, chemotherapy or both and/or amputations and mutilations resulting from surgical procedures ${ }^{(2)}$.

In light of this reality, the cancer patient needs social support from the network in which he or she is inserted, to aid in the acceptance of several situations and improve quality of life. Social support is a set of formal and informal relationships that cancer patients have in order to confront the challenges of this disease $\mathrm{e}^{(3)}$. It involves exchange relationships with reciprocal obligations and bonds of mutual dependence that benefit health status and can help to create a feeling of coherence and control over life ${ }^{(4)}$.

When this support is received, patients develop a sense of importance in a social network, respond positively to challenges and adopt positive behaviour, such as initiating or maintaining actions that promote wellbeing in their social circle and enhance the proposed treatment.

Changes in the healthcare system have been made to transfer patients with chronic diseases from in-patient to out-patient or home care, which increases the responsibility of family members and primary care providers in relation to the patient (4). The family may not be prepared to manage or administer this care and may need information on the disease and its treatment, training to obtain the technical skills required for home care, and support from basic healthcare units ${ }^{(4)}$.

The availability of an individual who can provide support or aid can protect patients with diseases from negative consequences, disease situ- ations or stress ${ }^{(5)}$. Social support is based on interpersonal relationships and has several functions, namely affective, emotional and material support. It is considered the process that provides positive effects on those who give and receive support, and allows people to increase their autonomy ${ }^{(6)}$.

The acknowledgement that social support can help cancer patients to adapt and maintain a quality of life means accepting the need to identify the arrangement of a support network made available to users so that care can be planned and implemented with quality. This concept was used as a basis for the study questions: Do social and demographic conditions interfere with the perception of social support of cancer out-patients? Which social support functions are affected? The aim of these questions was to analyse the relationship between social support and social and demographic characteristics of cancer out-patients.

\section{METHOD}

This is a quantitative cross-sectional study conducted in the out-patient High Complexity Cancer Care Centre (CACON) at the Caridade Hospital of Ijuí, in the north-eastern region of the state of Rio Grande do Sul (RS), Brazil. The sample was selected by convenience, according to demand for care, from July to December 2012. Inclusion criteria were to have received a medical cancer diagnosis, receiving treatment for at least three months, have autopsychic and allopsychic conditions to answer the instrument (confirmed in records), and residing in the municipality of Ijuí. Patients under the age of 18 were excluded.

Data were collected using a questionnaire consisting of two parts. The first part was used for social and demographic conditions: sex, age, self-referred race, marital status, education, family income and number of residents in the home (independent variables). The second part consisted of data on the characterization of social support (Medical Outcomes Study Social Support Survey (MOS-SSS), adapted to Portuguese ${ }^{(7)}$.

Patients were approached in the waiting room of the out-patient unit and were invited to participate in the survey. Those who accepted were led to a separate room to guarantee their privacy. All participants signed a consent form before the interview was initiated. 
The MOS-SSS comprises 19 items with five functional social support dimensions: material (4 questions - provision of practical resources and material aid); affective (3 questions - physical displays of love and affection); emotional (4 questions - expressions of positive affection, understanding, and trust); informational (4 questions - availability of people that provide advice or guidelines); positive social interaction ( 4 questions - availability of people to have fun or relax with). Patients selected the frequency in which each type of support was available in case of need: never (1), rarely (2), sometimes (3), almost always (4) or always (5) ${ }^{(7)}$.

Data were arranged using Epi-Info ${ }^{\circledR}$ 6.04, with double independent entries. After correcting errors and inconsistencies, statistical analysis was conducted using the Statistical Package for the Social Sciences (SPSS) ${ }^{\circledR}$ 18.0. Scores of social support dimensions were obtained by adding total points from the questions of each dimension divided by the maximum possible score of that same dimension. To standardize results of all dimensions, considering they contain a different number of questions, the ratio result (total obtained points/maximum dimension score) was multiplied by $100^{(7)}$.

The Mann-Witney and Kruskal-Wallis tests were used to compare social support averages and independent variables. The Pearson correlation was used to assess correlations between quantitative variables and social support. Associations were considered significant if $\mathrm{p}<0.05$. Internal consistency of the social support scale was assessed using Cronbach's Coefficient Alpha, and values above 0.70 show scale reliability in terms of construct measurement.

This study was approved by the Research Ethics Committee (CEP) of the Federal University of São Paulo, \#47215, June 29, 2012.

\section{RESULTS}

A total of 268 cancer patients undergoing treatment participated in the study. Average age of participants was $61.5( \pm 14.9)$, ranging from 18 to 106 years of age. Most patients were women (64.2\%), married or living with a companion (61.2\%); had not finished their primary education (53.7\%); had per capita family income of up to one (1) minimum wage $(59.3 \%)$, and $78 \%$ were from homes with two to four residents, as shown in Table 1.
In the five social support dimensions, the option "always" obtained the highest response percentage. Average scores ranged from 82.36 \pm 24.42 (positive interaction), 85.39 \pm 19.81 (informational), $87.98 \pm 18.68$ (emotional), 88.52 18.56 (material) and $93.50 \pm 14.44$ (affective), with a minimum score of 20 and maximum of 100 .

Overall Cronbach's Alpha of the social support scale was $\alpha=0.92$ (average $=82.9$ and $\mathrm{DP}=14.5$ ), with the lowest variation in the material dimension, with $\alpha=0.78$ (average $=17.7$ and $\mathrm{DP}=3.7$ ), and the highest variation in the positive Interaction dimension, with $\alpha=0.91$ (average $=16.5$ and $\mathrm{DP}=4.9$ ).

Correlations were made between social support dimensions and the number of people who lived in the residence, age of patients and per capita family income. In relation to correlations between dimensions, results showed that the material dimension had a significantly very low correlation with the dimensions affective $(\mathrm{r}=0.231 ; \mathrm{p}<0.01)$ and positive interaction $(\mathrm{r}=0.268 ; \mathrm{p}<0.01)$, a significantly low correlation with emotional support $(\mathrm{r}=0.366 ; \mathrm{p}<0.01)$ and a moderate correlation with informational $(\mathrm{r}=0.416 ; \mathrm{p}<0.01)$. The dimension affective showed a significantly moderate correlation with informational $(\mathrm{r}=0.558$; $\mathrm{p}<0.01)$ and a significantly high correlation with dimensions emotional $(\mathrm{r}=0.625 ; \mathrm{p}<0.01)$ and interaction $(\mathrm{r}=0.610 ; \mathrm{p}<0.01)$. The dimension emotional showed a significantly high correlation with dimensions informational $(\mathrm{r}=0.762 ; \mathrm{p}<0.01)$ and positive interaction $(\mathrm{r}=0.640 ; \mathrm{p}<0.01)$. The dimension informational presented a significantly strong correlation with the dimension interaction $(\mathrm{r}=0.601 ; \mathrm{p}<0.01)$. Results also showed a significantly very low correlation between dimensions affective and positive interaction with per capita family income $(\mathrm{r}=0.136 ; \mathrm{p}<0.05$ and $\mathrm{r}=0.182$; $\mathrm{p}<0.01$, respectively).

Table 2 shows comparisons of social support averages, according to social and demographic characteristics.

In comparison, male patients received significantly higher material social support with statistical differences $(\mathrm{p}=0, .00)$, emotional $(\mathrm{p}=0.007)$ and informational $(\mathrm{p}=0.006)$. Patients that stated mixed race as their ethnic group had the lowest averages for affective social support (0.010), emotional social support $(\mathrm{p}=0.002)$ and informational $(\mathrm{p}=0.045)$. 
Table 1 - Distribution of patients undergoing cancer treatment at the CACON, according to characteristics. Ijuí/Rio Grande do Sul, Brazil, 2012.

\begin{tabular}{|c|c|c|}
\hline Socio-demographic characteristics & $\mathbf{N}$ & $\%$ \\
\hline \multicolumn{3}{|l|}{ Sex } \\
\hline Female & 172 & 64.2 \\
\hline Male & 96 & 35.8 \\
\hline \multicolumn{3}{|l|}{ Age } \\
\hline 18-39 years & 88 & 32.8 \\
\hline $40-59$ years & 87 & 32.5 \\
\hline 60-106 years & 93 & 34.7 \\
\hline \multicolumn{3}{|l|}{ Marital status } \\
\hline Married or with companion & 165 & 61.6 \\
\hline Single or without companion & 103 & 38.4 \\
\hline \multicolumn{3}{|l|}{ Education } \\
\hline No schooling & 13 & 4.9 \\
\hline Incomplete Primary Education & 144 & 53.7 \\
\hline Completed Primary Education & 27 & 10.1 \\
\hline Incomplete Secondary Education & 13 & 4.9 \\
\hline Completed Secondary Education & 40 & 14.9 \\
\hline Incomplete Higher Education & 9 & 3.4 \\
\hline Completed Higher Education & 15 & 5.6 \\
\hline Completed Higher Education with Graduation & 7 & 2.6 \\
\hline \multicolumn{3}{|l|}{ Per capita* family income (in minimum wages) } \\
\hline No wages & 3 & 1.1 \\
\hline Up to 1 & 159 & 59.3 \\
\hline 1 to 2 & 68 & 25.4 \\
\hline 2 to 3 & 18 & 6.7 \\
\hline 3 to 4 & 13 & 4.9 \\
\hline 5 to 10 & 7 & 2.6 \\
\hline \multicolumn{3}{|l|}{ Residents at home } \\
\hline 1 person & 39 & 14.6 \\
\hline 2 to 4 people & 209 & 78.0 \\
\hline 5 to 9 people & 20 & 7.5 \\
\hline Total & 268 & 100 \\
\hline
\end{tabular}

Source: Data from authors. * National minimum wage in December $2012=$ BRL622.00.

\section{DISCUSSION}

Age group analysis showed that distribution of malignant neoplasm is practically equal among age groups of young adults of up to 39 years of age, mature adults up to 59 years old and the elderly, over 60.
This distribution of cancer in lower age groups was found in other studies that analysed the negative impact of this occurrence in financial aspects and the constitution and maintenance of family functionality ${ }^{(8-9)}$.

A study conducted in a benchmark cancer centre in parts of the northern and north-eastern 
Table 2 - Comparison of social support averages, according to social and demographic characteristics of patients undergoing cancer treatment. Ijuí/RS, Brazil, 2012.

\begin{tabular}{|c|c|c|c|c|c|c|c|c|c|c|}
\hline \multicolumn{11}{|c|}{ Social Support Dimensions } \\
\hline \multirow[t]{2}{*}{ Variable } & \multicolumn{2}{|c|}{ Material } & \multicolumn{2}{|c|}{ Affective } & \multicolumn{2}{|c|}{ Emotional } & \multicolumn{2}{|c|}{ Informational } & \multicolumn{2}{|c|}{$\begin{array}{c}\text { Positive } \\
\text { Interaction }\end{array}$} \\
\hline & Average & $\mathbf{p}$ & Average & $\mathbf{p}$ & Average & $\mathbf{p}$ & Average & $\mathbf{p}$ & Average & $\mathbf{p}$ \\
\hline Sex* & & 0.000 & & 0.277 & & 0.007 & & 0.006 & & 0.055 \\
\hline Female & 85.2 & & 93.5 & & 86.3 & & 83.1 & & 81.4 & \\
\hline Male & 94.5 & & 93.5 & & 90.9 & & 89.6 & & 84.1 & \\
\hline Ethnic Group*** & & 0.633 & & 0.010 & & 0.002 & & 0.045 & & 0.429 \\
\hline White & 88.7 & & 93.8 & & 88.2 & & 85.4 & & 82.5 & \\
\hline Black & 92.5 & & 82.2 & & 80.0 & & 72.5 & & 69.2 & \\
\hline Mixed Race & 87.7 & & 96.9 & & 92.1 & & 89.4 & & 84.6 & \\
\hline Indigenous & 82.5 & & 85.3 & & 46.3 & & 61.3 & & 70.0 & \\
\hline $\begin{array}{l}\text { Currently } \\
\text { Employed ** }\end{array}$ & & 0.850 & & 0.645 & & 0.534 & & 0.807 & & 0.292 \\
\hline Yes & 87.8 & & 93.9 & & 88.2 & & 85.3 & & 86.9 & \\
\hline No & 88.7 & & 93.4 & & 87.9 & & 85.4 & & 81.4 & \\
\hline Marital Status* & & 0.280 & & 0.574 & & 0.726 & & 0.231 & & 0.879 \\
\hline Married & 88.8 & & 93.5 & & 87.8 & & 84.5 & & 82.1 & \\
\hline Single & 88.1 & & 93.6 & & 88.3 & & 86.8 & & 82.9 & \\
\hline
\end{tabular}

Source: Data from authors. * Mann-Witney Test $\quad * *$ Kruskal-Wallis Test

regions of Brazil, which analysed 505 cancer patients, showed that average age was 59.18 years and $26.53 \%$ of cases were 50 years old or younger ${ }^{(10)}$. In this study, $67.2 \%$ were between 18 and 59 years old, which reinforces the need of a progressively unique strategy in public services for patients with cancer in this age group. Most of the patients in this investigation were women $(64.2 \%)$, but the incidence of cancer is equally distributed among both sexes in the global evaluation.

In developing countries, however, the prevalence among women shows a higher survival rate (close to 25\%), considering that the most fatal types of cancer affect the male population ${ }^{(11)}$. The incidence balance between men and women is a result of the numerous social roles currently assumed by most women. Excessive workloads in double or triple shifts can lead to stress, keeping in mind that their insertion in the work market does not exempt them from domestic activities and raising children. This has resulted in an accumulation of attributes that can contribute to imbalances in the organism ${ }^{(12)}$.
The studied samples characteristically received few years of schooling. A study on the prevalence of chronic diseases in the Brazilian population showed that inequality in living conditions of the adult population, assessed by years of schooling, is associated with the prevalence of chronic conditions, most of which are generally found in the less favoured segments of society ${ }^{(13)}$.

The incidence and estimate of cancer is greater in low-income populations, considering that they are more exposed to risk factors and have reduced access to healthcare services ${ }^{(14)}$. In this study, most patients stated that per capita family income was less than one (1) minimum wage; together with the patients that stated they received up to two minimum wages, the total is $84.7 \%$ of interviewed patients.. Impoverishment of the population, added to costs incurred when a family member becomes sick, reduces the available resources required to meet basic needs. In spite of the national health service (Sistema Único de Saúde - SUS), which is free and universal in Brazil, the individual cost of disease 
is still high due to extra costs of diagnosis and treatment that consequently contribute to greater impoverishment of these families ${ }^{(1)}$.

In addition to these population characteristics that reveal vulnerability, the occurrence of signs and symptoms of sickness can cause social problems that interfere with daily life and reduce the ability to work, relate to friends and family members and, corroborating the social difficulties, cancer can cause psychological problems ${ }^{(15)}$.

In relation to the number of residents at home, most patients stated they lived with two to four people, which can elucidate the favourable results of scores in all social support dimensions. A study conducted in Thailand corroborates these data, in which patients with cancer had satisfactory social support levels with an average above $99.46^{(15)}$.

Affective support that involves expressions of love, consideration, affection and interest presented the highest score, especially for interviewees who stated they had a steady job, among those who were married and those with the highest per capita income. Social support can come from bonds between people and groups, which include natural collaborators (family), informal groups (self-help) and formal and institutionalized groups, such as organizations for the sick, that can create the support networks of patients ${ }^{(16)}$. In particular, social support of family and friends helps to reduce the anguish of symptoms ${ }^{(15)}$.

Material support mentioned by the interviewees was high $(88.5 \%)$, especially among those who referred to themselves as being black and among single patients. This support refers to the help of others in case of need and also reflects access to healthcare services and actions from other people that help to solve practical activities ${ }^{(17)}$.

In terms of the emotional support dimension, the interviewees also indicated satisfactory results, especially among those of mixed race and among men, who stated they were not currently working and were single. Emotional support is defined as empathy, trust, love, affection, listening and interest $^{(18-19)}$. It is related to availability of someone to speak to, feelings of wellbeing and feeling loved and respected ${ }^{(18)}$. It should be noted that the studied population resided in a municipality in the interior of the state, where interpersonal relationships are preserved due to geographic proximity and cultivated due to a slower-paced life.
The proximity of interviewees with an extended support network can be verified with the same satisfactory response in the informational support dimension, especially among single patients. Informational support is measured by means of access of individuals to counselling, suggestions, guidelines and information. This pursuit strategy of social support is essentially important when the information is based on diagnosis and treatment, as information on treatment and care provision resources offered by the circle in which they are inserted can help reduce anxiety and tension during the initial stages and onset of this pathology ${ }^{(2)}$.

Information from healthcare professionals can reduce uncertainties in relation to the disease and promote trust when dealing with the symptoms. Furthermore, social support has a direct impact on insecurity/uncertainty and the greater the support of family members and healthcare professionals, the lesser the uncertainty in relation to treatment and pathology $\mathrm{y}^{(3-15)}$.

The positive interaction dimension obtained the lowest score, with an average of $=82.36 \pm 24.42$, showing that leisure activities are the least accessible, which can truly lead to difficulties in social interaction, considering the incapacities and limitations the disease and treatment can cause, possibly worsened with the low income of the studied population, that is, the lower the income, the lesser the options of leisure and entertainment.

In this dimension, most of the interviewees were married, were currently employed or working, and had the highest per capita income. Moreover, data showed a tendency for greater social support among male patients $(\mathrm{p}=0.055)$. They presented the highest score for the dimension positive interaction, probably related to the preserved dynamics of interpersonal relationships; a better clinical condition that the workers can maintain despite the period of treatment; and greater purchasing power for leisure activities.

Results obtained after analysing variables with social support dimensions corroborate findings of literature, in which men received more social support than women. Similar studies discuss that the activities of women in the family organization are still based on providing care and, for the practice of caring, they organize themselves, prioritize activities, extend the social network and assume the responsibility, especially in cases of sickness ${ }^{(20)}$. 
Contributions of this study that should be emphasized are that cancer treatment is not restricted to the biological aspect of care and that the dimensions that make up social support should be topics of concern for healthcare professionals. Another contribution of the study is the acknowledgement that some groups are more vulnerable than others, and that cultural factors should be observed in order to identify them and help these groups overcome difficulties in the initial stages of cancer. In this sense, when women are diagnosed with cancer, considering that they are culturally accepted as providers of care, they do not receive the same attention and social support as men. In order to improve care and educational practices, the study should provide means for the creation of a protocol that targets the diagnosis of social support and its management based on educational actions, information on the rights of patients and government and non-governmental institutions in the region.

\section{CONCLUSION}

This study revealed that all dimensions of the social support scale (material, affective, emotional, informational and interaction) are positively correlated, that is, the greater the support received by patients, the greater the other dimensions will become. However, when social and demographic variables were analysed, this study showed higher social support scores among male patients (material, emotional and informational) and of mixed race ethnic groups (affective, emotional and informational). Furthermore, results showed that per capita family income had a positive association with affective social support and interaction.

In terms of study limitations, data were obtained from a specific population group, with its cultural, economic and social configurations and of the care provided by the SUS, which does not have the same characteristics and potentialities in all regions of Brazil. Consequently, this study can serve as a model for investigations on other groups of cancer patients and for the characterization of social support.

\section{REFERENCES}

1 Ministério da Saúde (BR), Secretaria de Vigilância em Saúde, Departamento de Análise de Situação de Saúde. Plano de ações estratégicas para o enfrentamento das doenças crônicas não transmissíveis
(DCNT) no Brasil 2011-2022. Brasília: Ministério da Saúde; 2011 [citado 2013 jun 17]. Available in http://portal.saude. gov.br/portal/arquivos/pdf/ cartilha_dent_pequena_portugues_espanhol.pdf

2 Santana JJRA, Zanin CR, Maniglia JV. Pacientes com câncer: enfrentamento, rede social e apoio social. Paidéia. 2008;18(40):371-84.

3 Rodrigues JSM, Ferreira NMLA. Estrutura e funcionalidade da rede de apoio social do adulto com câncer. Acta Paul Enferm. 2012; 25(5): 781-7.

4. Sanchez KOL, Ferreira NMLA, Dupas G, Costa DB. Apoio social à família do paciente com câncer: identificando caminhos e direções. Rev Bras Enferm. 2010; 63(2):290-9.

5 Sherbourne CD, Stewart AL. The MOS social support survey. Soc Sci Med. 1991; 38(6): 705-14.

6 Pinto KRTF, Marcon SS. A família e o apoio social recebido pelas mães adolescentes e seus filhos. Cienc Cuid Saúde. 2012;1 1(supl):153-9.

7 Griep RH, Chor D, Faerstein E, Lopes C. Apoio social: confiabilidade teste-reteste de escala no Estudo Pró-Saúde. Cad. Saúde Pública. 2003; 19(2): 625-34.

8 Rodrigues JSM, Ferreira NMLA. Caracterização do perfil epidemiológico do câncer em uma cidade do interior paulista: conhecer para intervir. Rev Bras Cancerol. 2010; 56(4):431-41.

9 Leite ICG, Nunes LC, Moreira RC, Couto CA, Teixeira MTB. Mortalidade por câncer de boca e faringe. Rev Bras Cancerol. 2010; 56(1): 17-23.

10 Rêgo AGS, Borges ICV, Valença RJV, Teles JBM, Pinto LSS. Câncer colorretal em pacientes jovens. Rev Bras Cancerol. 2012; 58(2):173-80.

11 Guerra MR, Gallo CVM, Mendonça GAS. Risco de câncer no Brasil: tendências e estudos epidemiológicos mais recentes. Rev Bras Cancerol. 2005; 51(3): 227-34.

12 Pafaro RC, De Martino MMF. Estudo do estresse do enfermeiro com dupla jornada de trabalho em um hospital de oncologia pediátrica de Campinas. Rev Esc Enferm USP. 2004; 38(2):152-60.

13 Barros ABM, Francisco PSMB, Zanchetta LM, César CLG. Tendências das desigualdades sociais e demográficas na prevalência de doenças crônicas no Brasil, PNAD: 2003- 2008. Cienc Saude Colet. 2011; 16(9): 3755-68. 
14 Ministério da Saúde (BR). Instituto Nacional de Câncer José Alencar Gomes da Silva. Estimativa 2012: incidência de câncer no Brasil. Rio de Janeiro; 2011. Available in: http://portal.saude.sp.gov.br/ resources/ses/perfil/gestor/homepage/estimativas-de-incidencia-de-cancer-2012/estimativas_incidencia_cancer_2012.pdf

15 Somjaaivong B, Thanasilp S, Preechawong S, Sloan $\mathrm{R}$. The influence of symptons, social support, uncertainty, and coping on health-related quality of life among cholangiocarcinoma patients in Northeast Thailand. Cancer Nurs. 201 1;34(6):434-42.

16 Canesqui AM, Barsaglini RA. Apoio social e saúde: pontos de vista das ciências sociais e humanas. Cienc Saude Colet. 2012; 17(5): 1103-14.
17 Gómez MMG, Gómez MI. El apoyo social: estrategia para afrontar el cáncer de cérvix. Av Enferm. 2012; $30(1): 32-41$.

18 Kolankiewicz ACB. Relações entre os sintomas clínicos, o apoio social e a interferência na vida diária de pacientes oncológicos [Tese]. São Paulo (SP): Universidade Federal de São Paulo; 2013.

19 Pisoni AC, Kolankiewicz ACB, Scarton J, Loro MM, Souza MM, Rosanelli CLSP. Dificuldades vivenciadas por mulheres em tratamento para o câncer de mama. J Res: Fundam Care Online. 2013; 5(3): 194-201.

20 Salci MA, Marcon SS. De cuidadora a cuidada: quando a mulher vivencia o câncer. Texto Contexto Enferm. 2008; 17(3): 544-51.

\author{
Author's address / Endereço do autor / \\ Dirección del autor \\ Adriane Cristina Bernat Kolankiewicz \\ Rua Tiradentes, 231, Centro \\ 98700-OOO, Ijuí, RS \\ E-mail: adri.saudecoletiva@gmail.com
}

Received: 09.09.2013

Approved: 20.01.2014 